\title{
PROFESSIONAL TRAINING OF STUDENTS OF INSTITUTIONS OF HIGHER EDUCATION IN THE PROCESS OF PHYSICAL EDUCATION WITH THE USE OF CHOREOGRAPHIC TEACHING METHODS ПРОФЕСІЙНА ПІДГОТОВКА СТУДЕНТІВ ЗАКЛАДІВ ВИЩОЇ ОСВІТИ
В ПРОЦЕСІ ФІЗИЧНОГО ВИХОВАННЯ ІЗ ЗАСТОСУВАННЯМ
ХОРЕОГРАФІЧНИХ МЕТОДІВ НАВЧАННЯ
}

The article deals with the professional training of university students in the process of physical education with the help of new types of aerobics using choreographic teaching methods. The experiment involved 500 students. Analyzed more than 100 literary sources of available data on the features of the study of the development of the physical qualities of female students using dance means of fitness.

Objective: to develop and substantiate the method of using choreographic methods in the process of extracurricular classes of students of the first and second courses. The theoretical knowledge and practical experience on the selection of content and organization of physical education of female students of higher educational institutions in the process of extracurricular classes are generalized, and an experimental survey and comparative analysis of indicators of physical condition and physical fitness of first and second year students who do not play sports are conducted who attend the aerobics section.

The results marked a significant interest in physical education classes using the proposed methodology. It has been established that the main ways to improve the physical education of students in the education system can be shaped by the need for health promotion by means of dancing types of aerobics. The prospect of improving the physical education of students.

This makes it possible to develop solutions in the course of physical education in higher education institutions in order to successfully implement an educational health care strategy. The introduction of well-founded choreographic methods in the study allows students to significantly increase the level of physical fitness and functional state of the organism.

Practical recommendations can be applied in the educational process of institutions of higher education as a separate component or as an addition to existing student learning systems and for the development of teaching aids.

Key words: aerobics, health, students, choreography, physical abilities.

у статmі розглядається професійна під готовка студентів закладів вищої освіти в прочесі фрізичного виховання за допомогою нових видів аеробіки з використанням хореографрічних методів навчання. В експерименті брали участь 500 студентів. Проаналізовано понад 100 літературних джерел наявних даних, присвячених особливостям дослідження розвитку фрізичних якостей студенток із використанням засобів таниювальних видів фрітнесу.

мета: розробити і обгрунтувати методику використання хореограсрічних методів у прочесі позааудиторних занять студентів перших і других курсів. Узагальнено теоретичні знання і практичний досвід з питань відбору змісту та організації фрізичного виховання студенток закладів вищої освіти в процесі позааудиторних занять, а також проведені експериментальний опитування та порівняльний аналіз показників фрізичного стану та фьізичної підготовленості студентів перших і других курсів, які не займаються спортом, і тих, хто відвідує секцію аеробіки. Результати: зафріксовано значний інтерес до занять із фрізичного виховання з використанням запропонованої методики. Встановлено, що основними шляхами вдосконалення фрізичного виховання студентів в системі освіти можуть бути сорормовані потреби в зміцненні здоров'я засобами танцювальних видів аеробіки.

Виявлена перспектива вдосконалення фрізичного виховання студентів. Це дає можливість розробляти варіанти рішень на заняттях фізичного виховання в закладах вищої освіти з метою успішної реалізації освітньої здоров'язбережувальної стратегіі. Впровадження обгрунтованих у дослідженні хореографрічних методів дозволяє студентам значно підвищити рівень фрізичної підготовленості та фуункіонального стану організму. Практичні рекомендації можуть бути застосовані в освітньому прочесі закладів вищої освіти як окремої складової або як доповнення до існуючих систем навчання студентів а також для розробки навчальних посібників.

Ключові слова: аеробіка, здоров'я, студенти, хореографрія, фрізичні здібності.
Recently, Ukraine has seen a steady trend towards deterioration of the population and students' health in particular. It is paid attention on this tend in the public documents concerning physical education in the higher education institutions and in the research of specialists in the field of physical culture and sports.

So, research of V.Arefyeva (2014), Y. Vaskova (2013), G. Griban (2004), L. Kozhevnikova (2001), A. Timoshenko (2011), O. Shkoly (2014) found that during the period of study in higher education the number of students that apply to preparatory and special medical group, increasing from $5.3 \%$ in the first year and up to
$14.4 \%$ in the fourth. Accordingly, there is a decrease in the number of students belonging to the main group from $84,0 \%$ to $70.2 \%$.

In addition, the research of S. Ermakova (2012), A. Kibalnyk (2009), Zh. Kozinoyi (2014), T. Krutsevich (2014), O. Kuznetsovoyi (2004), N. Popychevoyi, T. Sychovoyi (2012) indicate a low level of students' physical development, physical preparedness and capacity. The authors [5], [8] note that as a result of defective decision of the primary goals of physical education most graduates, after graduation, are not physically able to perform professional duties with the quality 
and intensity that is required by modern conditions of market economy. Thus, the functional potential of young people, depended on social and economic welfare of the country, is decreasing.

According to this, one of the most important tasks of physical education in higher educational establishment is to strengthen health, to improve physical fitness and physical condition of students. A number of authors, such as Sergei Bubka (2004), P. Ermakov (2010), Z. Merkulova (2008), N. Moskalenko (2005), M. Nosko (2013), T. Roters (2011) noted a decline in students motivation and interest in physical education, pointing to the monotony of training material, insufficient efficiency of existing methods and forms of training that almost do not meet the requirements of modern higher education.

So, the problem of modernization of physical education in the higher educational establishment through the introduction of innovative approaches to organization of educational process taking into account students motivation and new, modern types of motor activity, that encourage them to engage in physical exercises is actual. And therefore the relevance of this issue of the research is obvious, and it is required explanation and analysis.

Objectives of the study. 1 . To summarize the theoretical knowledge and practical experience on issues of content selection and organization of students' physical education of higher educational institutions in extracurricular classes.

2. To do a comparative analysis of indicators of physical condition and physical fitness of students who are not involved in sports, and those who visit the section of the cheer dance (cheerleading).

3. To develop and experimentally validate a methodology for the use of cheer dance means in extracurricular classes with students of 1-2 courses of higher educational institutions.

The object of study: students physical education of non-core universities in extracurricular classes.

Subject of research: methods of cher-dans show means using in extracurricular classes with students of 1-2 courses of non-core universities.

Research methods: analysis and generalization of literature data on the research topic; a summary of best practices of physical education specialists and coaches through interviews and questionnaires; teaching observation for competitive and training activities; pedagogical testing (determination of the level of development of motor abilities), pedagogical experiment, methods of mathematical statistics.

The contingent of studied students is the first and second year of students of Municipal establishment "Kharkiv humanitarian-pedagogical Academy» Kharkiv regional Council. The experiment was attended by 450 students aged $17-23$ years.

The experimental and control groups were formed. Each group was engaged to 27 students. The division of students into groups was carried out according to the results of a survey about the choice of motor activity in the classroom for physical education. Therefore, the dance types of cheerleading: cheer dance, cheer dance show were included into the classes of the experimental group [1], [2], [4]. The control group trained on a model curriculum for physical education in higher educational institutions of Ukraine III-IV accreditation levels. The study was carried out in stages.

In the first phase pedagogical observation, a preliminary study of the student physical condition and level of physical fitness, the analysis and generalization of scientific and methodical literature, the definition of objectives, tasks, object and subject of research, selection of research methods were held; experimental methods of teaching were worked out. The experimental method of teaching was aimed at reducing body weight, normalization of metabolism, quitting bad habits, to improving physical qualities and overall health and to promoting healthy life and the motivation to physical exercises.

The content of courses on cheer dance show included dance unit, built on the basic elements of cheerleading: pirouettes, stretching, waving, cheer jumping, leap-jumping, show elements of programs, and did not contain elements of acrobatics, backing (support of partner), pyramids. Therefore, this technique is available to a wide range of students. In cheer dance show exercises the motion and music of different dance styles (jazz, funk, pop, rap, lyrical dance, etc.) were presented. Therefore, this type of cheerleading promotes not only physical development, growth of motor qualities of students, but also their aesthetic education.

In the second stage the pedagogical experiment was held, the essence, which was that the use of cheer dance in extracurricular classes with students of 1-2 courses, had a stimulatory effect of physical education aimed at the formation and promotion of health, improving of physical condition and physical fitness level.

The third phase involved processing and comparative analysis of the obtained results, which allowed to establish the effectiveness of methods of use of cheer dance means in extracurricular classes of students of higher educational institutions.

The study was conducted according to the "Consolidated plan of research work in the sphere of physical culture and sports for 2011-2015" in topic 2.4 "Theoretical-methodological basis of individualization in physical education and sports" (№ of state registration 0112U002001) and according to the scientific-research works, which are financed from the state budget of the Ministry of education and science of Ukraine in 20142015 "Theoretical-methodological basis for the use of informational, pedagogic and medical-biological technologies for formation of healthy lifestyle" (№ of state registration 0113U002003) and "Theoretical-methodological support for the formation of healthy lifestyle of the individual in terms of the institution in the context of European integration" (№ of state registration 0114U001781).

A number of authors have addressed the issues of improving the system of physical education of universities in various fields by introducing the optimal content of the training materials, new forms and means. So, L.N. Barybina, S.A. Semashko, I.V. Kryventsova 
(2011) developed a system of classes in aerobics, using an individual approach. V. Mishchenko, T. Kyune, V. Vinogradov, L. Melnyk, A. Nevyadomska (2011) implemented an 8-week exercise program of mostly power character in combination with the vibratory influences of the rotation type with the aim of improving students'force capabilities.

N.V. Lyulina, L.V. Zakharova (2011) developed an experimental technique in aerobics with the use of simulation exercises from different sports. S.V. Uskov (2011) addressed the problem of preserving and strengthening the psychological health of schoolchildren and students through practice martial arts as example of karate. G.V. Yasko, O.B. Kashuba (2011) implemented in the educational process of students methods of Hatha yoga.

N.M. Balamutova (2012) applied hydropedagogy and hydrokinesiotherapy, as one mean of students'rehabilitation with scoliosis. T.V. Sychova (2012) introduced the elements of aerobics by using special X-box equipment. Zh.L. Kozina, S.S. Yermakov, T.A. Bazylyuk, O.V. Voloshyna (2012) introduced the Aquafitness of gaming focus with the use of special technical devices.

N.P. Voronov, O.M. Stolyarenko (2012) studied the health impact of gymnastic exercises with the help of modern computer technologies, directed on formation of the correct posture of the students. T.M. Bala (2013) investigated the effect of cheerleading exercises on physical health and motor preparedness of high school students.

I.O. Zinchenko (2013) examined the construction of training process of sportsmen in cheerleading on the stage of specialized basic training. A.S. Innytska (2014) studied the methodology of teaching physical training of students on the basis of bodyflex and pilates. A.V. Fomenko (2014) used an innovative method of application of non-traditional types of gymnastics in students'extracurricular classes. But works devoted to the study of teaching methods by means of cheer dance, as well as their influence on the physical condition and level of physical preparedness of students of the universities were not discovered.

It should be noted that cheer dance show is a modern, progressive, spectacular form of motor activity, which is gaining popularity in our country. This is one of the varieties of cheerleading. In our opinion, the using in the process of physical education of specially chosen cheer dance exercises has positive impact on the indicators of physical condition and physical fitness and will increase the interest of students towards physical education and sport.

Therefore, there is an urgent need for working out of method for using of means cheer dance in the process of student physical education. The greatest potential for using of such means lie in the effective organization of sports and recreational activities of students, extracurricular activities (T.Y. Krutsevich, 2010; L.P. Sergienko, 2009; Y.M. Furman, 2011). However, classes in physical education with use of modern technologies (in particular cheer dance) in comparison with the traditional practice are reflected in greater interest of students, providing students with the latest information regarding health and increasing energy expenditure, as well as the results of the study determine the dominant preferences of students of higher educational institutions to study various types of physical exercises.

The practical significance of the research is to develop methods of using cheer dance show exercise, their rational use in the process of extracurricular classes of the university students for improving their physical condition and interest in physical education. Also these materials can be used during the formation and training of student teams on cheer dance show to participate in competitions at various levels.

Conclusions. 1. Introduction of grounded in research methods of cheer-dance show classes allows students to significantly improve the level of physical preparedness and functional state of the organism.

2. Practical recommendations along with the using of extracurricular work can be applied in the educational process of physical culture institutes, faculties of physical education pedagogical universities, higher schools of physical culture as a stand-alone component, or as a Supplement to existing systems of training and education, students training of pedagogical faculties and the development of training manuals.

The prospects for further research. It wll be focus on the comparative characteristics of tudents physical condition and physical fitness of third and fourth courses that engage cheer-dance show.

\section{REFERENCES:}

1. Школа О.М., Журавльова І.М. Теорія та методика навчання: аеробіка. Х. : ФОП Бровін О.В., 2014. 265 c.

2. Хоули Е.Т., Френкс Б.Д. Оздоровительный фитнес. К. : Олимпийская литература, 2000. 368 с.

3. Бала Т.М. Комплексна оцінка впливу вправ черліденгу на фрізичне здоров'я та рухову підготовленість школярів середніх класів: Х., 2013. 22 с.

4. Губарева Е.С. Развитие педагогической технологи в оздоровительніх видах гимнастики. НУФВСУ. К., 2001. 201 c.

5. Захарина Е.А. Формувание мотивации к двигательной активности в процессе фризического воспитания студентов высших учебных заведений. К., 2008. 23 с.

6. Зінченко І.О. Побудова тренувального процесу спортсменів в черлідінгу на етапі спеціалізованої базової підготовки. Х., 2013. 20 с.

7. Ільницкая А.С., Козина Ж.Л., Коробейник В.А., Ільницкий С.В., Тсеслитска М., Станкевич Б., Пилевска В. Методика применения оздоровительных систем бодифлекса и пилатеса в фризическом воспитании студентов. Педагогика, психология $и$ медико-биологические проблемы фризического воспитания и спорта, 2014. № 2. С. 25-33. doi: 10.6084/ m9.figshare.923510.

8. Зайцев В.П., Прусик К., Ермаков С.С. Физическая рекреация в структуре активного отдыха студентов. Физическое воспитание студентов. Х. : ХООНОКУ-ХНАДУ. 2011. № 1. С. 68-77. 